\title{
Article \\ Carbstone Pavers: A Sustainable Solution for the Urban Environment
}

\author{
Hadi Kazemi Kamyab ${ }^{1, *}$, Peter Nielsen ${ }^{1}\left(\mathbb{D}\right.$, Peter Van Mierloo ${ }^{2}$ and Liesbeth Horckmans ${ }^{1}$ (D) \\ 1 Sustainable Materials, Vlaamse Instelling voor Technologisch Onderzoek, Boeretang 200, \\ B-2400 Mol, Belgium; peter.nielsen@vito.be (P.N.); liesbeth.horckmans@vito.be (L.H.) \\ 2 Orbix, Henry Fordlaan 84, B-3600 Genk, Belgium; Peter.Vanmierloo@orbix.be \\ * Correspondence: hadi.kamyab@vito.be; Tel.: +32-14335220
}

check for updates

Citation: Kazemi Kamyab, H.; Nielsen, P.; Van Mierloo, P. Horckmans, L. Carbstone Pavers: A Sustainable Solution for the Urban Environment. Appl. Sci. 2021, 11, 6418. https://doi.org/10.3390/ app11146418

Academic Editors: Philip Van den Heede, Natalia Mariel Alderete and Theodore E. Matikas

Received: 28 May 2021

Accepted: 7 July 2021

Published: 12 July 2021

Publisher's Note: MDPI stays neutra with regard to jurisdictional claims in published maps and institutional affiliations.

Copyright: (C) 2021 by the authors Licensee MDPI, Basel, Switzerland. This article is an open access article distributed under the terms and conditions of the Creative Commons Attribution (CC BY) license (https:// creativecommons.org/licenses/by/ $4.0 /)$

\begin{abstract}
To reduce $\mathrm{CO}_{2}$ emissions from the building industry, one option is to replace cement in specific applications with alternative binders. The Carbstone technology is based on the reaction of calcium- and magnesium-containing minerals with $\mathrm{CO}_{2}$ to form carbonate binders. Mixes of carbon steel slag and stainless-steel slag, with tailored particle size distributions, were compacted with a vibro-press and subsequently carbonated in an autoclave to produce carbonated steel slag pavers. The carbonated materials sequester $100-150 \mathrm{~g} \mathrm{CO}_{2} / \mathrm{kg}$ slag. Compressive and tensile splitting strength of the resulting pavers were determined, and the ratio was found to be comparable to that of concrete. The environmental performance of the Carbstone pavers, with an average tensile splitting strength of 3.6 MPa, was found to be in compliance with Belgian and Dutch leaching limit values for construction materials. In addition, leaching results for a concrete mix made with aggregates of crushed Carbstone pavers (simulating the so-called "second life" of pavers) demonstrate that the pavers can be recycled as aggregates in cement-bound products after their product lifetime.
\end{abstract}

Keywords: carbonation; sustainable construction materials; alternative binders; vibro-pressing; tensile splitting strength; environmental quality; leaching

\section{Introduction}

Cement is the second most consumed material by mankind, after water. About $4.1 \mathrm{Gt}$ of cement is produced each year [1]. Traditional cement, or OPC (Ordinary Portland Cement), relies on high temperature $\left(1450^{\circ} \mathrm{C}\right)$ calcination of limestone to generate Portland clinker, emitting about 0.875 tonnes of $\mathrm{CO}_{2}$ per tonne of Portland clinker produced [2] Cement typically constitutes 10 to $15 \%$ of concrete, and although concrete has one of the lowest embodied energy demands per volume among materials [3], cement ends up being responsible for $5-10 \%$ of global $\mathrm{CO}_{2}$ emissions due to its massive scale of production [4]. Under a Business as Usual scenario, the cement industry may become responsible for up to a third of anthropogenic $\mathrm{CO}_{2}$ emissions by 2050, as a result of increased demand in developing countries and $\mathrm{CO}_{2}$ mitigating actions taking place in other sectors [5]. Unlike for other energy-intensive processes, $\mathrm{CO}_{2}$ emissions in cement production are mainly derived from the decarbonation of raw materials, i.e., limestone, and only $40 \%$ of the $\mathrm{CO}_{2}$ emissions are related to energy [2,6]. The use of green electricity or refuse-derived/biofuels can therefore only partially mitigate the production emissions.

Several pathways exist to reduce $\mathrm{CO}_{2}$ emissions from the building industry. Concrete mixes can be optimized to avoid overconsumption of cement, or the use of Portland clinker in cement can be reduced by using SCMs (supplementary cementitious materials) to partially replace the OPC [6]. In some applications, the use of cement can be avoided entirely by using alternative binders, if these materials are locally, and to some extent, abundantly available. These alternative materials, such as carbonate-based binder materials [7,8], alkali-activated materials [9], and Calcium Sulfoaluminate (CSA) systems [10,11], can provide local solutions for certain applications. One such alternative is the Carbstone 
technology [12], where calcium- and magnesium-rich minerals from steel slags react with $\mathrm{CO}_{2}$ to produce carbonate binders. In this process, non-hydraulic steel slags (stainless-steel (electric arc furnace and argon oxygen decarburization slag) and basic oxygen furnace slags) are transformed into high-quality construction materials (up to $130 \mathrm{MPa}$ compressive strength) without using any cement. An additional advantage is that the carbonated materials sequester 100-150 $\mathrm{g} \mathrm{CO}_{2} / \mathrm{kg}$ slag [13]. Life cycle assessments (LCA) of carbonated steel slag products have shown that the recovery of pure $\mathrm{CO}_{2}$ from industrial waste gas for carbonation of steel slag products accounts for a large part of the energy consumption, and thus, significantly contributes to the global warming potential (GWP) or carbon footprint of the carbonated products [14-16]. The net $\mathrm{CO}_{2}$ footprint is, however, still negative, meaning that more $\mathrm{CO}_{2}$ is captured in the carbonated steel slag products than is emitted during the production process [14-16]. To reduce the $\mathrm{CO}_{2}$ emissions of the carbonation process further, flue gas can be used instead of pure $\mathrm{CO}_{2}$ gas, and a direct flowing flue gas can be used instead of a traditional electricity-based carbonation curing chamber or autoclave reactor [16]. This may, however, also influence the $\mathrm{CO}_{2}$ uptake of the products and needs to be further investigated. Taking into account the avoided $\mathrm{CO}_{2}$ emissions from cement, up to $18.5 \mathrm{~kg} \mathrm{CO}_{2}$-eq. emission reduction per $\mathrm{m}^{2}$ paver can be achieved [17].

Initial development of the Carbstone technology focused on the production of interior wall building blocks, having compressive strength in the range of 30 to $50 \mathrm{MPa}[12,18]$. The production process was adapted from traditional sand-lime brick production, and used hydraulic press compaction and autoclave curing. In 2018, within the nationally funded Stapsteen project (Vlaanderen Circulair project 153), pavers were identified to be high potential applications for the urban environment. Pavers are typically made by vibration pressing, and the strength requirement (according to EN 1338 [19]) is formulated in terms of tensile splitting strength (min. 3.6 MPa). As such, this change in application required a twofold adaptation in the Carbstone process: from hydraulic to vibration press, and from optimization of compressive to tensile splitting strength. In concrete-based building products, mechanical properties are commonly linked to compressive strength, since access to a compressive strength test machine is simple and more frequent, and it can be evaluated experimentally in a straightforward manner without difficulty in its interpretation. The relation between compressive and split tensile strength in concrete has been studied extensively over the years, and many data are available in the literature $[20,21]$. Formulas have been given by various standards to estimate the tensile strength of concrete from its compressive strength [22-24]. However, in the case of Carbstone products, the main mechanical property evaluated so far has been the compressive strength, and the relationship between the compressive strength and split tensile strength has not been investigated or established. Steel slags are by-products, with potentially significant concentrations of residual metals such as $\mathrm{Cr}$, Mo, and V. Stainless-steel slags typically contain 1 to $7 \mathrm{wt} \%$ $\mathrm{Cr}$ [25]. The concentration of these residual metals may depend on the source, chemical composition, cooling history and demetallization process of the steel slags [26,27]. The use of steel slags or other by-products (e.g., as unbound or bound aggregate in concrete) can lead to significant leaching of the residual metals. Carbonation can limit or increase the leaching by reducing the $\mathrm{pH}$, since the leaching of most pollutants is $\mathrm{pH}$-dependent [28], by decreasing the porosity [29], or by mineralogical changes [30]. The extent of leaching of Carbstone products needs to be evaluated and should also include an evaluation of their use as recycled secondary aggregates in concrete, as their use in concrete is generally associated with a significant $\mathrm{pH}$ increase that may result in a remobilization of pollutants. To the best of our knowledge, the environmental impacts of carbonated steel-slag-based pavers (or carbonated steel-slag-based construction blocks) as recycled (secondary) aggregates in concrete have not been evaluated. This is essential as this may impact the 'closing the loop' of concrete, and, in particular, of recycled concrete aggregates.

To increase the confidence in carbonated steel slag products, and their acceptance in the market in applications that can replace concrete as construction material, it is of paramount importance to show that these products comply with all local environmental 
standards. In addition, it should be ascertained that at the end of its service life, these products can be recycled in a sustainable way (e.g., as unbound aggregate or as cement bound aggregate) such as construction and demolition waste (C\&DW), without affecting the concrete loop of recycled aggregates. The objective of this research is twofold: (1) To carry out a preliminary investigation into the relationship between compressive and tensile splitting strength for Carbstone pavers, and to compare it to that of concrete. (2) To evaluate the environmental performance of a Carbstone paver, which conforms to the tensile split cylinder requirements of EN 1338:2003. The environmental performance of the Carbstone pavers in different lifecycles will be compared to the leaching limits set by VLAREMA [31] in the Flemish region, and the Dutch soil quality decree in the Netherlands [32].

\section{Materials and Methods}

\subsection{Materials and Characterization Methods}

Steel slag (LD-Slag) from Arcelor Mittal Gent, and three stainless-steel slag fractions from Orbix-Stinox ${ }^{\circledR} 2 / 6$ fraction, Stino ${ }^{\circledR} 0 / 2$ fraction, and Carbino ${ }^{\circledR}$ - were used in this study. These steel slag fractions are produced by Orbix during demetallization of electric arc furnace and argon oxygen decarburization slags from stainless-steel production.

Figure 1 shows the particle size distribution (PSD) of the received raw materials measured by sieve analysis. For the sieve analysis, a sieve tower was made with $350 \mathrm{~g}$ of material. Shaking time was set to $10 \mathrm{~min}$. In case of laser diffraction, Horiba's Partica mini LA-350 Laser Scattering Particle Size Distribution Analyzer was used to measure and estimate the PSD of the Carbinox ${ }^{\circledR}$. Before the measurement, $20 \mathrm{~mL}$ of isopropanol and $0.07 \mathrm{~g}$ of homogenized Carbinox were placed in a $50 \mathrm{~mL}$ plastic tube. An external ultrasonication probe was used for $2 \mathrm{~min}$ at 250 Watts to ensure a good dispersion of the powder.

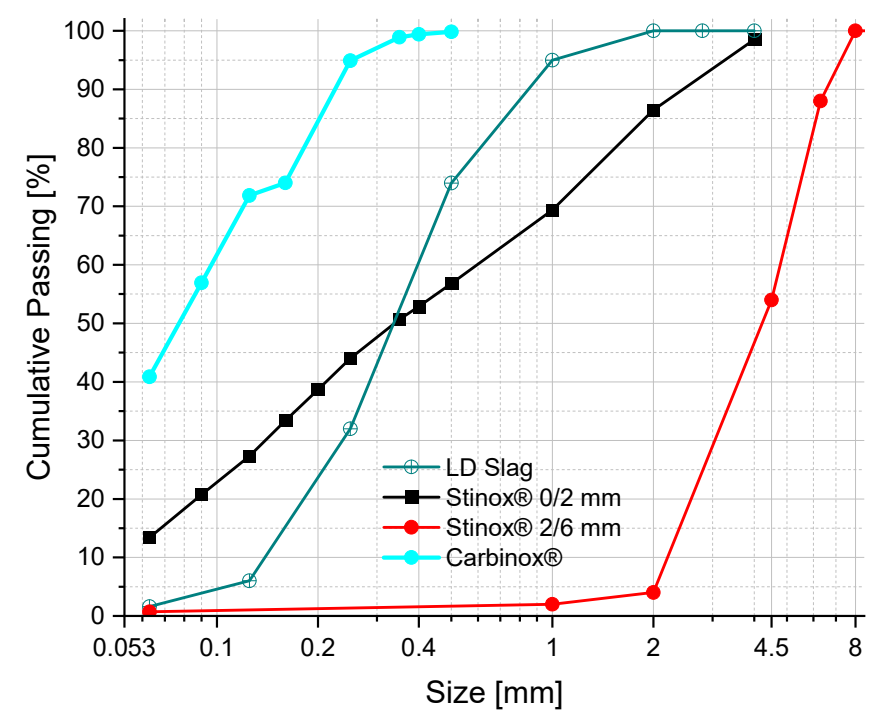

Figure 1. Particle size distribution of Carbinox ${ }^{\circledR}$, LD Slag, Stinox ${ }^{\circledR} 2 / 6$, and Stinox ${ }^{\circledR} 0 / 2$ obtained using Sieve analysis.

Chemical composition was determined using a high-performance energy dispersive XRF spectrometer with polarized X-ray excitation geometry (HE XEPOS, Spectro Analytical Systems, Kleve, Germany). The instrument was equipped with a $50 \mathrm{~W}$ tungsten end window tube (max. $60 \mathrm{kV}, 2 \mathrm{~mA}$ ) and a Silicon Drift Detector. For signal optimization, different targets were applied. All analyses were performed under Helium atmosphere. For analysis of loose powder, an XRF sampling cup, provided with a $4 \mu \mathrm{m}$ Prolene foil (Chemplex), was filled with the sample and subsequently placed in the autosampler of the EDXRF system. The quantification was performed using a pre-calibrated software package for (semi)-quantitative analysis of geological materials. Table 1 summarizes the chemical 
compositions of the LD-Slag, Carbinox ${ }^{\circledR}$ and Stinox ${ }^{\circledR}$ fractions. Note for the elements Na and $\mathrm{Mg}$, there is a measurement uncertainty of $30 \%$, and the values for $\mathrm{S}$ are indicative. For all other elements, the measurement uncertainty is approximately 10 to $20 \%$.

In addition, ICP-AES analysis was performed to determine the content of $\mathrm{Cr}, \mathrm{Ni}, \mathrm{Mo}$, $\mathrm{V}$, and $\mathrm{Ba}$. The metal content in the sample was determined with inductively coupled plasma-atomic emission spectrometry (ICP-AES) after acid digestion using a microwave system according to CMA/2/II/A.3. About $0.5 \mathrm{~g}$ of sample was weighed in the digestion vessel. Then, the following acids were separately added: $6 \mathrm{~mL} \mathrm{HCl}, 2 \mathrm{~mL} \mathrm{HNO} 3$ and $4 \mathrm{~mL}$ of HBF4. The digestion vessel was placed into the microwave unit (6 positions, Milestone) and the following digestion process was applied: $2 \mathrm{~min}$ at $250 \mathrm{~W}, 2 \mathrm{~min}$ at $0 \mathrm{~W}, 5 \mathrm{~min}$ at $250 \mathrm{~W}, 5 \mathrm{~min}$ at $400 \mathrm{~W}$ and $5 \mathrm{~min}$ at $500 \mathrm{~W}$. At the end of the program, the vessels were cooled down to room temperature, transferred to a volumetric flask, and filled with up to $100 \mathrm{~mL}$ with ultrapure water. The digested solution was measured with an ICP-AES (Perkin Elmer, Optima 3000 DV). The fluoride (F) content was measured by ion-selective electrode analysis after hydro-pyrolysis of the solid sample.

The mineralogy of the materials (milled to a particle size $<63 \mu \mathrm{m}$ ) was determined by Rietveld analysis of X-ray powder diffraction (XRD) scans using an X'Pert PRO XRD Philips diffractometer equipped with a Co tube $(\lambda=1.7890100 \mathrm{~nm})$. Measurements were carried out between $5^{\circ}$ and $120^{\circ} 2 \theta$ with a step size of approximately $0.013^{\circ}$ and $48 \mathrm{~s}$ net integration time per step. The resulting diffractograms were analyzed using HighScore Plus version 4.0 software. The quantification of the mineral phases was carried out adapting the method reported in [33], which consists of a quantitative mineral analysis using the Rietveld method combined with an external standard for determining the content of amorphous phases. The main mineralogy of the LD-slags is characterized by portlandite, $\beta-\mathrm{Ca}_{2} \mathrm{SiO}_{4}$, Srebrodolskite, (all between 8 and $18 \mathrm{wt} . \%$ ) and minor contents of lime, calcite, katoite, cuspidine, quartz, and magnesioferrite (all $<5 \mathrm{wt} . \%$ ); the amorphous content is about $25 \mathrm{wt} . \%$. For the Carbinox and Stinox samples, merwinite, bredigite, cuspidine, $\gamma-\mathrm{Ca}_{2} \mathrm{SiO}_{4}$ and gehlenite-akermanite are the major phases (between 7 and $20 \mathrm{wt} . \%$ ) and the minor phases are $\beta-\mathrm{Ca}_{2} \mathrm{SiO}_{4}$, wollastonite, periclase, magnetite, spinel and calcite $(<5 \mathrm{wt} . \%)$. The amorphous content is about $25 \mathrm{wt} . \%[18,34]$.

Table 1. Chemical composition of the LD slags and Carbinox ${ }^{\circledR}$ and Stinox ${ }^{\circledR}$ from stainless-steel slags determined by ED-XRF analysis, except for F, which was measured by ion-selective electrode analysis after hydro-pyrolysis of the solid sample.

\begin{tabular}{ccccc}
\hline & LD Slag & Carbinox $^{\circledR}$ & $\begin{array}{c}\text { Stinox } \\
\mathbf{0} / \mathbf{2} \mathbf{~ m m}\end{array}$ & $\begin{array}{c}\text { Stinox }^{\circledR} \\
\mathbf{2 / 6} \mathbf{~ m m}\end{array}$ \\
\hline $\mathrm{CaO}(\%)$ & 51 & 40 & 38 & 39 \\
$\mathrm{SiO}(\%)$ & 14 & 37 & 38 & 38 \\
$\mathrm{MnO}(\%)$ & 2.5 & 0.77 & 0.98 & 0.93 \\
$\mathrm{MgO}(\%)$ & 3.8 & 13 & 14 & 14 \\
$\mathrm{Na} \mathrm{O}_{2}(\%)$ & 3.6 & 0.81 & 0.92 & 0.70 \\
$\mathrm{P}_{2} \mathrm{O}_{5}(\%)$ & 1.7 & 0.28 & 0.25 & 0.28 \\
$\mathrm{Al}_{2} \mathrm{O}_{3}(\%)$ & 2.8 & 5.5 & 6.3 & 5.9 \\
$\mathrm{FeO}(\%)$ & 20 & 0.54 & 0.68 & 0.35 \\
$\mathrm{TiO}_{2}(\%)$ & 0.65 & 0.55 & 0.68 & 0.68 \\
$\mathrm{Cr}_{2} \mathrm{O}_{3}(\%)$ & 0.15 & 2.1 & 2.2 & 1.9 \\
$\mathrm{MoO}_{3}(\%)$ & 0.00083 & 0.0049 & 0.011 & 0.0048 \\
$\mathrm{~V}_{2} \mathrm{O}_{5}(\%)$ & 0.580 & 0.051 & 0.046 & 0.045 \\
$\mathrm{~S}^{(\%)}$ & 0.15 & 0.22 & 0.20 & 0.16 \\
$\mathrm{~F}(\%)$ & 0.33 & 1.8 & 0.8 & na * \\
\hline * & & & &
\end{tabular}

\subsection{Mixtures}

To better understand the relationship between the compressive strength and tensile splitting strength of the carbonated materials, 8 mixes were designed consisting of various combinations of LD Slag, and the three stainless-steel slag fractions (Table 2). Note that the 
as-received LD Slag $(0-3 \mathrm{~mm})$ and Carbinox ${ }^{\circledR}(<0.5 \mathrm{~mm})$ were milled to below 250 microns, to allow for better compaction, and optimum reactivity during the carbonation process. In addition, by decreasing the particle size distribution of the LD Slag, the free lime can easily convert to calcium hydroxide during the hydration process, which mitigates the possibility of cracking (due to the hydration of lime) during carbonation of the pavers. Furthermore, the last column in Table 2 shows the moisture content (water/solid) ratio to which the mixtures were brought $24 \mathrm{~h}$ before compaction and carbonation to let hydration occur. In addition, using the proper range of moisture content will allow better compaction in the vibro-press. Figure 2 shows the overall cumulative particle size distribution of mixtures 1 to 8 . Note that once the relationship between the compressive strength and tensile splitting strength was established based on Mix 1 to Mix 8, a mix was designed to validate and verify the observed relationship for a mixture which was not part of the experiment, shown in the last row in Table 2 as Mix Final.

Table 2. Mixtures used to investigate the relation between compressive strength and split tensile strength. Last column in the table shows the moisture content (water/solid) ratio, to which the mixtures were brought $24 \mathrm{~h}$ before compaction and carbonation.

\begin{tabular}{|c|c|c|c|c|c|c|}
\hline & $\begin{array}{c}\text { LD-Slag } \\
(<150 \mu \mathrm{m}) \\
\%\end{array}$ & $\begin{array}{c}\text { Carbinox } \\
(<150 \mu \mathrm{m}) \\
\%\end{array}$ & $\begin{array}{c}\text { Stinox } \\
(0 / 2 \mathrm{~mm}) \\
\%\end{array}$ & $\begin{array}{c}\text { Stinox } \\
(2 / 6 \mathrm{~mm}) \\
\%\end{array}$ & $\begin{array}{c}\text { Stinox } \\
(2 / 10 \mathrm{~mm}) \\
\%\end{array}$ & $\begin{array}{c}\text { Moisture } \\
\text { Content }\end{array}$ \\
\hline Mix1 & 70 & & 30 & & & 14.0 \\
\hline Mix2 & 50 & & 50 & & & 11.4 \\
\hline Mix 3 & 25 & 25 & 50 & & & 10.8 \\
\hline Mix 4 & 30 & & 70 & & & 10.8 \\
\hline Mix 5 & 15 & 15 & 70 & & & 10.8 \\
\hline Mix 6 & 20 & & 40 & 40 & & 5.0 \\
\hline Mix 7 & 30 & & 20 & 50 & & 4.5 \\
\hline Mix 8 & 25 & & 15 & 60 & & 4.0 \\
\hline Mix Final & 25 & 35 & 20 & & 20 & 13.0 \\
\hline
\end{tabular}

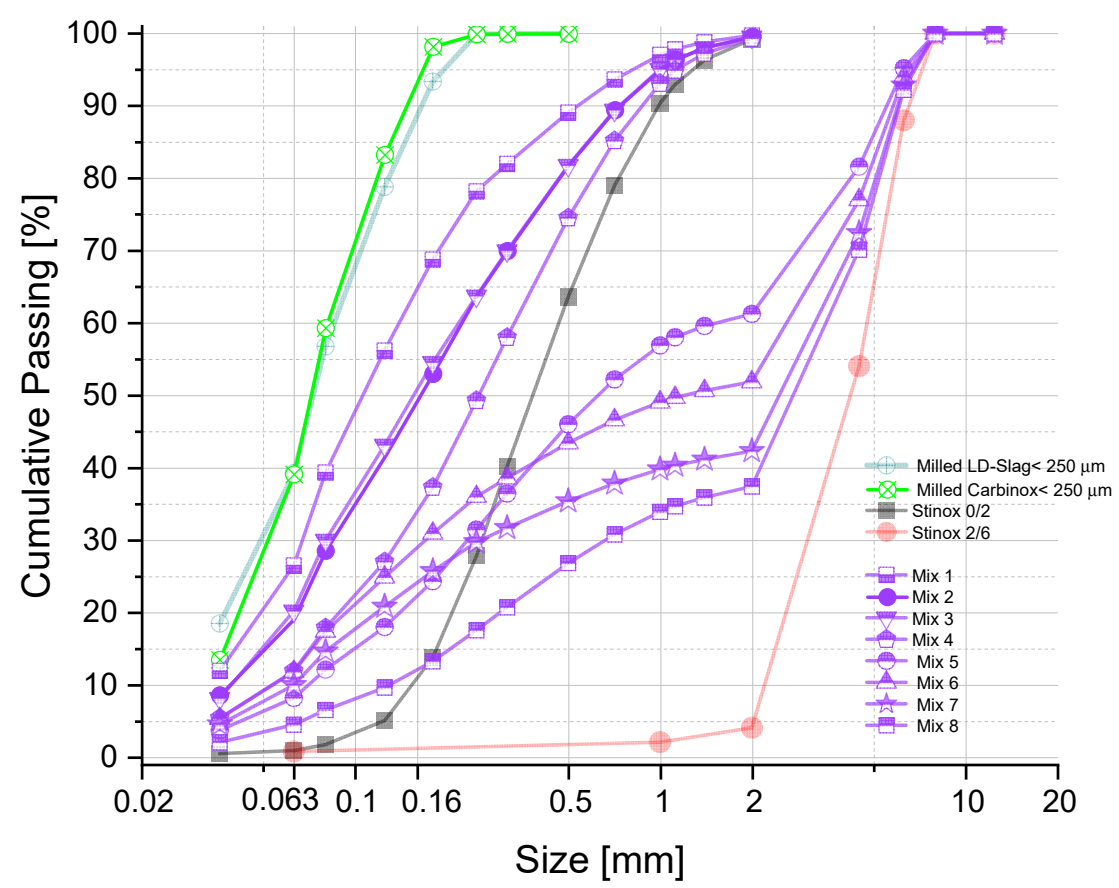

Figure 2. Overall cumulative particle size distribution of mixtures 1 to 8 , along with cumulative particle size distribution of the components used in designing of the mixtures. 


\subsection{Carbonation Methodology}

As schematically shown in Figure 3, the steps needed to make the pavers are as follows:

1. Pretreatment stage of each mixture: All components used to make the mixtures were first dried at $105^{\circ} \mathrm{C}$. Then, components were combined according to Table 2, to make 3 pavers with dimensions $220 \times 220 \times 80 \mathrm{~mm}$ for each mixture. The mixtures were then placed in a bucket and sealed firmly to allow the mixture to hydrate for $24 \mathrm{~h}$ and avoid drying before the shaping stage.

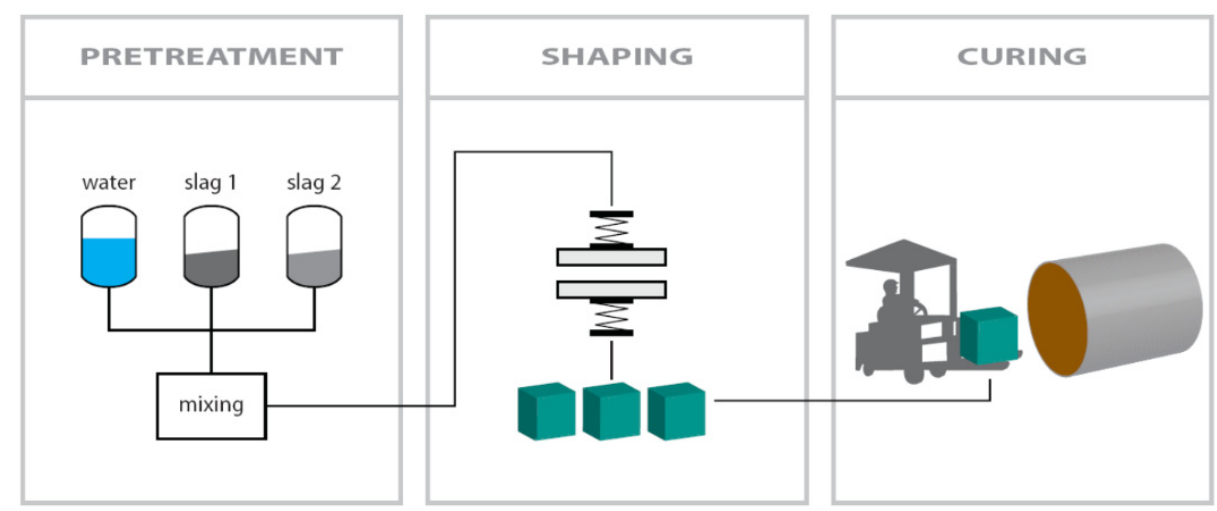

Figure 3. Schematic drawing of the carbonation process at lab-scale [12].

2. Shaping stage: A Metalika Vibro-press VPS 2000/1 GT with a frequency of $100 \mathrm{kHz}$ and a capacity of 8-12 pavers per $30 \mathrm{~s}$ cycle at Orbix was used to make the pavers. For each mixture, the hydrated mixes were placed in three of the $220 \times 220 \times 80 \mathrm{~mm}$ paver's molds. Several filling steps followed by compaction through vibration/stamping steps are needed to obtain an optimum compaction, and thus, compressive strength. The compaction stage gave the newly shaped pavers sufficient green strength to be handled and placed in the autoclave for carbonation (Figure 4).

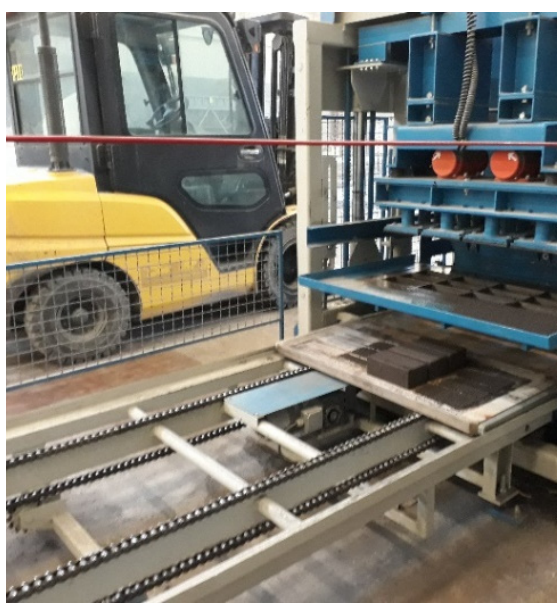

(a)

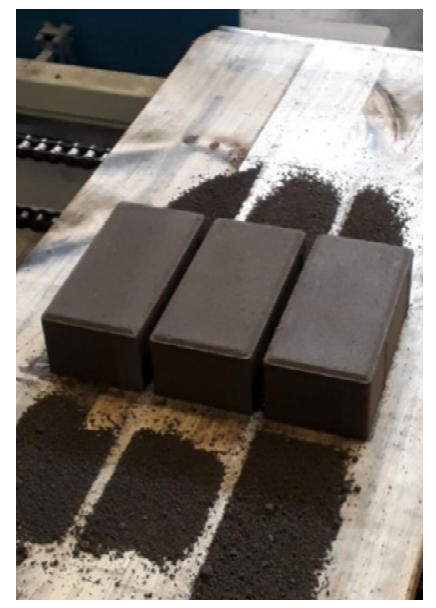

(b)

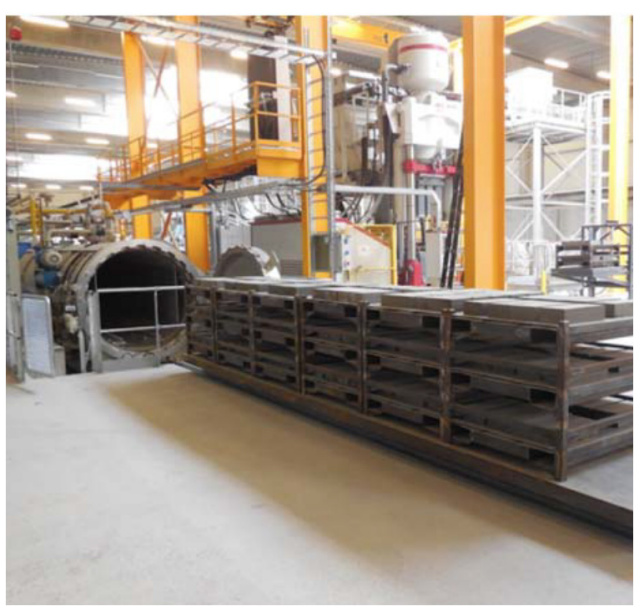

(c)

Figure 4. (a) Metalika vibro-press used to make the pavers at the Orbix site in Farciennes; (b) Pavers before carbonation; (c) Scholtz $\mathrm{CO}_{2}$ autoclave at the Orbix site.

3. Carbonation stage: The fresh pavers were placed in a Scholz autoclave at Orbix in Farciennes for carbonation. The carbonation was carried out at 6 bars (with 100\% $\mathrm{CO}_{2}$ ) at $35^{\circ} \mathrm{C}$ for $72 \mathrm{~h}$ (Figure 4 ).

After carbonation, some of the samples were cut in half, and a solution of phenolphthalein indicator was used to evaluate the extent of carbonation based on $\mathrm{pH}$. After contact 
with the phenolphthalein indicator solution, a pink color is indicative of a $\mathrm{pH}>9$, indicating incomplete carbonation. Note that for Mix 1 and Mix 2, the pavers were cut in two, resulting in a smooth surface, while for the rest of the mixes, the (rough) halves of the split tensile strength were used (Figure 5).

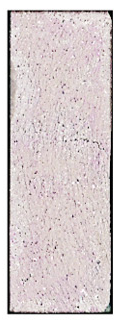

Mix 1

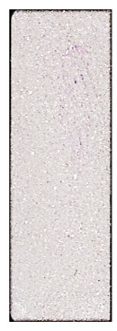

Mix 2

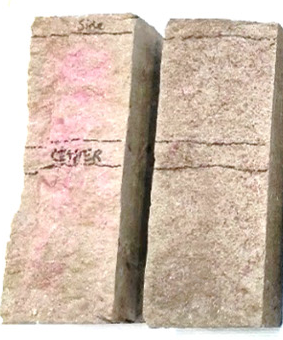

Mix 3

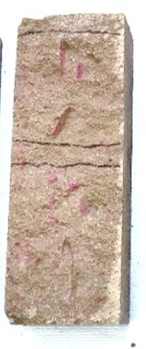

Mix 5

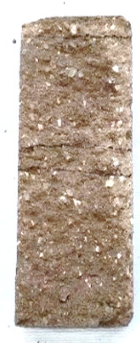

Mix 6

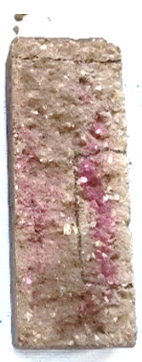

Mix 7

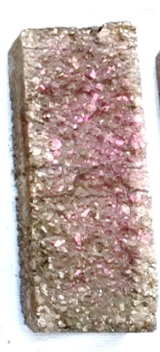

Mix 8

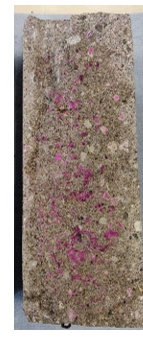

Mix Final

Figure 5. Carbonation fronts identified by phenolphthalein indicator of the mixes. Note that in case of Mix 1 and 2 , the samples were cut, while in case of Mix 3 to 8 , and the mix final the phenolphthalein indicator test was carried out on the blocks after splitting tensile.

\subsection{Mechanical Strength Measurement Methods}

Once the pavers were carbonated, the methods described below were used to evaluate various mechanical properties of the mixtures.

Non-destructive ultrasonic pulse velocity (UPV) has been used extensively to assess the quality and homogeneity of concrete [35]. UPV has also been used to follow the changes in concrete properties over time, whether those changes were due to hydration, enhancing the stiffness of the concrete or deterioration due to durability-related issues [36]. Finally, although UPV is proportional to the elastic modulus/stiffness of the concrete, the pulse velocity method has been used to estimate the strength of concrete, once the relation between compressive strength and UPV has been established [37,38]. Effects such as improper compaction, changes in water to cement ratio, type and quality of coarse aggregates can influence the elastic stiffness and thus, the pulse velocity of concrete [39]. Many of the examples mentioned above can also be used in the case of carbonation. Here, UPV was used to assess the quality of the carbonated pavers, as a proxy for the carbonation degree of the pavers. The UPV measurements were also correlated with the compressive strength of the Carbstone pavers. The UPV test was carried out on the $220 \times 220 \times 80 \mathrm{~mm}$ pavers following EN 12504-4:2004 with some adaptations. PUNDIT ${ }^{\circledR}$ PL-200 was used under direct through-transmission mode, with two $54 \mathrm{kHz} \varnothing 50 \mathrm{~mm} \times 46 \mathrm{~mm}$ transducers, one as a transmitter and one as a receiver. Knowing the travel distance is $220 \mathrm{~mm}$, the pulse velocity of the material was calculated to assess the quality of the pavers from each mixture after carbonation.

The split tensile test was carried out on the $220 \times 220 \times 80 \mathrm{~mm}$ pavers following EN 1338:2003 with some adaptations. The split tensile strength of the pavers was calculated based on Annex F.4 of the standard. According to the standard, the split tensile strength should not be lower than $3.6 \mathrm{MPa}$.

Eight samples of $40 \times 40 \times 40 \mathrm{~mm}$ were wet cut with a continuous rim diamond blade saw from pieces of the pavers from the split tensile strength test (approximately $220 \times 110 \times 80$ ). The compressive strength test was carried out on these samples. A loading rate of $2.4 \mathrm{kN} / \mathrm{s}$ was used. Note that according to EN 1338:2003, the compressive strength is not considered a requirement.

\subsection{Environmental Quality}

Based on the results obtained from the relationship between compressive strength and split tensile strength, the validated final mixture passing the 3.6 MPa split tensile strength 
requirement set by the EN 1338:2003 was selected to determine the environmental quality at the end of life phase.

The environmental quality of the pavers was tested according to the Flemish Materials Decree of the 23rd of December 2011, and the accompanying implementing decisions in VLAREMA of 17 February 2012. VLAREMA is an acronym for 'Decision of the Flemish Government establishing the Flemish regulations concerning the sustainable management of materials cycles and waste' [31]. It provides a clear framework for defining the end-ofwaste phase of a waste material.

Three pavers were crushed in different steps to obtain a $0-4 \mathrm{~mm}$ fraction that was used to perform an upstream column percolation test (according to CMA/2/II/A.9.1 and NEN 7373:2004 standards) (L/S $=10,7$ eluate fractions). In addition, two upstream column percolation leaching tests according to CMA/2/II/A.9.5 (L/S 10, 1 eluate fraction) were performed to establish the cumulative leaching at $\mathrm{L} / \mathrm{S}=10$ more firmly. These percolation tests are carried out to study the leaching behavior (percolation test in 7 fractions) and to establish if the material complies with the Flemish and Dutch environmental regulations. The performed percolation test is similar to the European prEN 16637-3:2020 standard. However, $95 \mathrm{wt} \%$ of the material was crushed to a grain size $<4 \mathrm{~mm}$, while in the European standard, a larger grain size is maintained. In the European standard, crushing is avoided as much as possible, i.e., crushing is only carried out in the case of an oversized fraction (size depending on the column diameter) or to fill a lack of fine grains less than $4 \mathrm{~mm}$. A subsample was milled for analysis of the total composition after microwave destruction in a mix of $\mathrm{HCl}, \mathrm{HNO}_{3}$ and $\mathrm{HBF}_{4}$ in a microwave oven (conform CMA/2/II/A.3).

To further support the environmental quality in a second life, a concrete mix was made with aggregates from crushed Carbstone pavers. This simulates what would happen in the so-called "second and third life", when Carbstone pavers are demolished, and the resulting fragments used as secondary aggregates in concrete. For the concrete mix, a worst-case situation was evaluated by replacing both the fine $(0-4 \mathrm{~mm})$ and coarse $(4-20 \mathrm{~mm})$ natural aggregates with $(100 \%)$ recycled Carbstone paver aggregates. This situation will never occur in practice, because Carbstone pavers will always be mixed with other construction and demolition wastes. Additionally, only part of the natural aggregates in concrete are generally replaced by recycled aggregates because of their technical properties (higher water absorption, etc.). CEM I was used, as this generally leads to the highest $\mathrm{pH}$, and therefore, worst-case scenario for leaching of most metals. After 28 days curing, the concrete was gently crushed to $<4 \mathrm{~mm}(95 \%<4 \mathrm{~mm})$ aggregates and subjected to upstream percolation tests (according to VLAREMA CMA/2/II/A.9.1 (7 fractions) and NEN 7373:2004).

\section{Results and Discussion}

\subsection{Relation between Compressive Strength and Splitting Tensile Strength}

Figure 5 shows the results of the phenolphthalein indicator solution test. In all mixtures, especially the ones containing larger particles, there are some non-carbonated pockets rather than carbonation fronts. Obviously, this observation is more vivid in the case of mixes with coarser Stinox aggregates. Overall, the mixtures were carbonated uniformly throughout.

UPV was used to assess the quality of the pavers after carbonation (Figure 6). It can be seen that in most cases, except Mix 1 and Mix 2, the UPV values have reached $3500 \mathrm{~m} / \mathrm{s}$; note that in the case of concrete classification, a UPV value between $3500 \mathrm{~m} / \mathrm{s}$ and $4500 \mathrm{~m} / \mathrm{s}$ is considered to be a good concrete quality [40]. Mixture 3 had the highest UPV, reaching approximately $4000 \mathrm{~m} / \mathrm{s}$.

Figure 7 shows that higher compressive strength results in higher split tensile strength. For a better visualization of the data, the ratio of splitting tensile to compressive strength versus paver's compressive strength was plotted (Figure 8). A clear trend emerged. In addition, the fitted line for many concrete data has also been shown for comparative reasons [20]. The trends are very similar to the ones from concrete, where samples with lower compressive strength have higher $\mathrm{f}_{\mathrm{tsp}} / \mathrm{f}_{\mathrm{c}}$. As the compressive strength increases, the increase in the 
split tensile strength is not as pronounced and thus, the ratio of split tensile to compressive strength as a function of compressive strength decreases significantly. Based on Figure 8, the pavers should have a minimum compressive strength in the range of $30-35 \mathrm{MPa}$, in order for their splitting tensile strength to be $3.6 \mathrm{MPa}$. However, more data are needed to confirm the observed trend, especially at high compressive strengths.

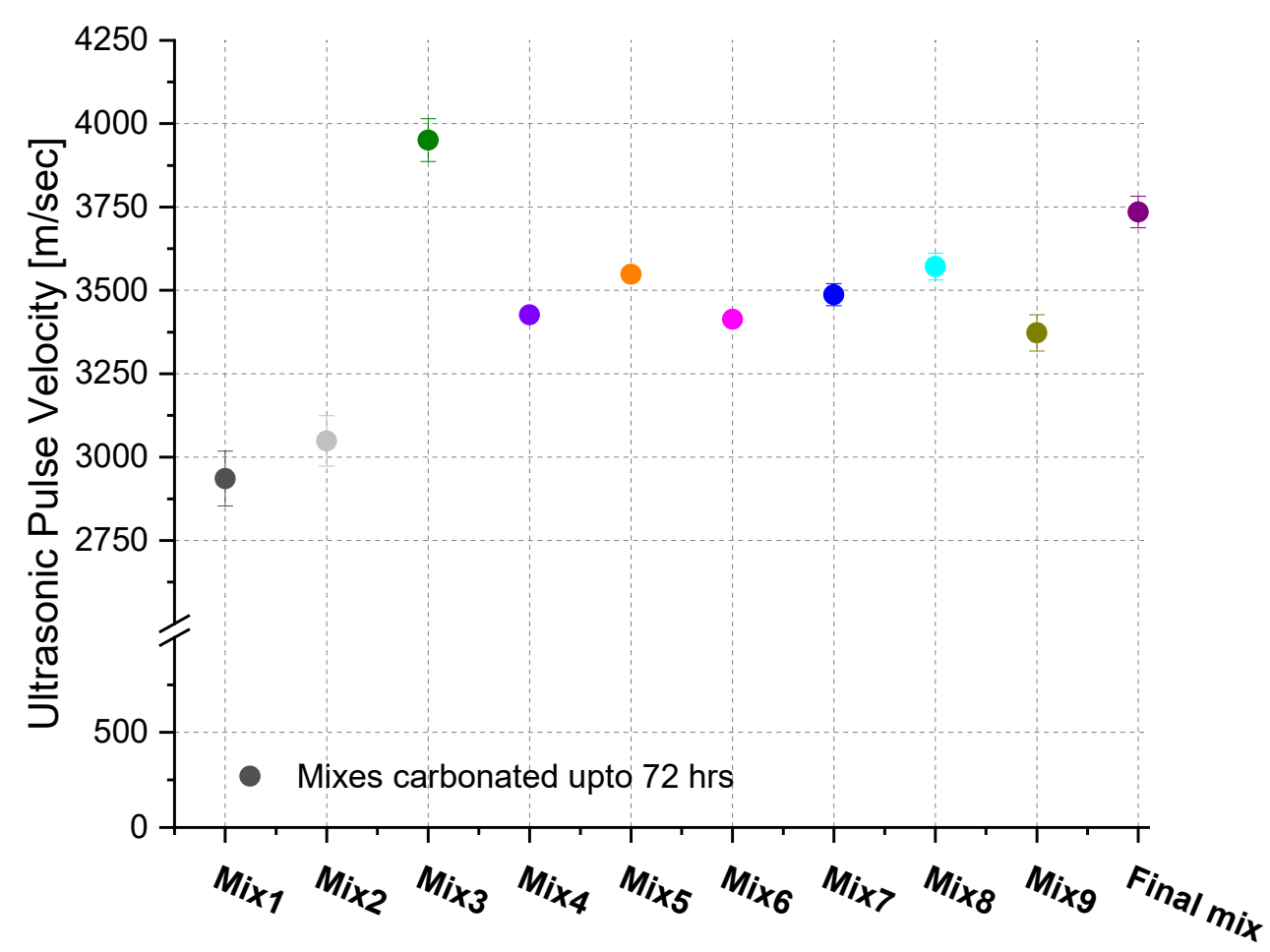

Figure 6. Ultrasonic pulse velocity of pavers up to $72 \mathrm{~h}$ of carbonation.

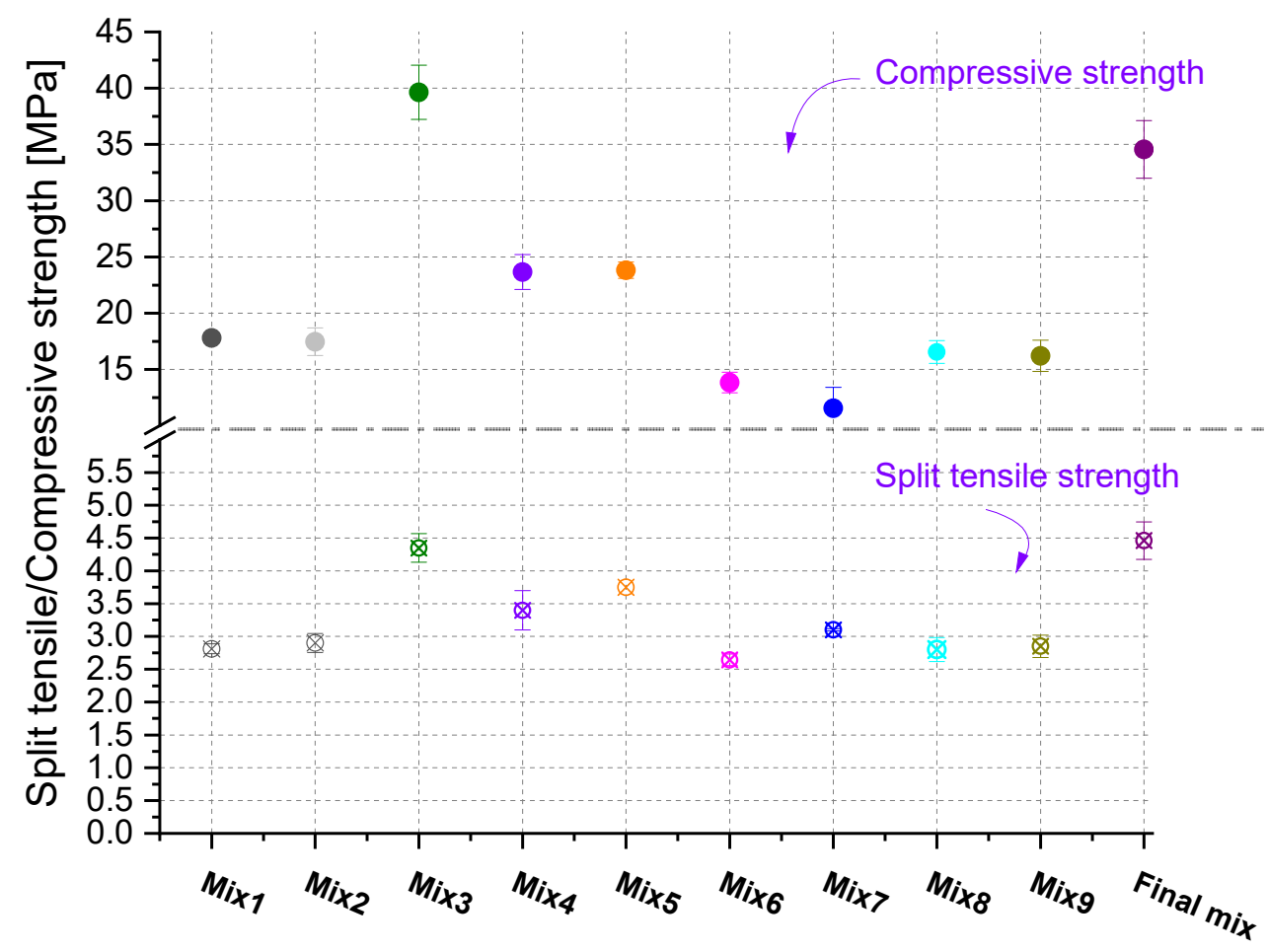

Figure 7. Split tensile and compressive strength of the pavers from various mixes. 


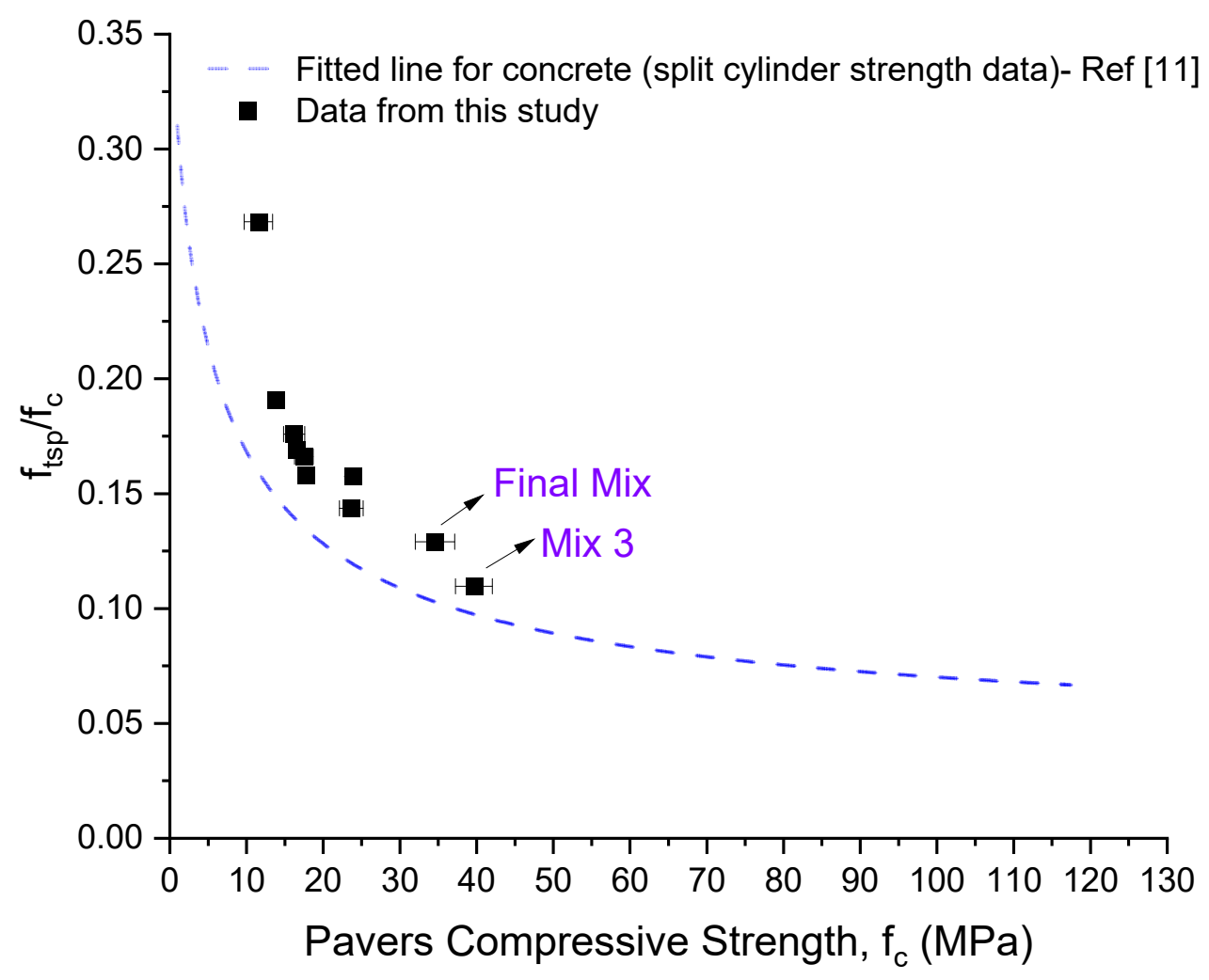

Figure 8. Ratio of splitting tensile to compressive strength versus paver's compressive strength.

\subsection{Environmental Quality}

For the final mix, which is the mix containing the highest amount of Carbinox and thus, the highest amount of potential pollutants, the environmental quality was established with regard to the leaching limits imposed by the Flemish government in the Flemish region and by the Dutch government in the Netherlands. The leaching values are compared with the current and (proposed) future VLAREMA legislation of the Flemish region, and with the Dutch soil quality decree ('regeling bodemkwaliteit') of the Netherlands (Table 3).

The results show that the environmental quality complies with the current and future VLAREMA legislation. For molybdenum, the Dutch soil decree limits are exceeded in two of the three leaching tests.

Fluoride leaching exceeds $(2 x)$ the Flemish target value and the Dutch limit value. However, although anion concentrations must be monitored in VLAREMA, they are not grounds for exclusion. In the Netherlands, application could be targeted to locations in direct contact with seawater or brackish water, for which the fluoride leaching limit is increased to $220 \mathrm{mg} / \mathrm{kg}$ dry matter.

The release mechanism for $\mathrm{Cr}, \mathrm{Mo}, \mathrm{Ba}, \mathrm{V}$ and the anions fluoride, chloride and sulphate was assessed following the guidelines of the European prEN 16637-3:2020 standard. For all other elements, the leaching concentrations were too low to properly determine the release mechanism. The leaching behavior as a function of cumulative L/S is shown in Figure 9. For all the elements, the release was $\mathrm{pH}$-dependent. Pearson's correlation coefficient was calculated for leachate concentrations of fractions 2 to 7 (Table 4). The concentrations in the leachate of fraction 1 were not included in the analysis, as the leaching in this fraction is often affected by wash-off. Note that for most elements ( $\mathrm{V}$ being the only exception), the leaching increases with increasing $\mathrm{pH}$. This indicates that a further decrease in the $\mathrm{pH}$, for example, by a better carbonation of the pavers, may lead to a lowering of the leaching concentrations. However, it also indicates that when recycling these materials in a concrete matrix, the leaching could increase because of the higher $\mathrm{pH}$ environment. 
Table 3. Total element content and leaching concentrations ( $\mathrm{mg} / \mathrm{kg}$ dry matter) as determined by upstream column percolation testing.

\begin{tabular}{|c|c|c|c|c|c|c|c|}
\hline & $\begin{array}{c}\text { Total } \\
\text { Concentration }\end{array}$ & $\begin{array}{l}\text { Column } \\
7 \text { Fractions }\end{array}$ & $\begin{array}{c}\text { Column } \\
1 \text { Fraction A }\end{array}$ & $\begin{array}{c}\text { Column } \\
1 \text { Fraction B }\end{array}$ & $\begin{array}{c}\text { VLAREMA } \\
\text { Annex 2.3.2B }\end{array}$ & $\begin{array}{l}\text { VLAREMA } \\
\text { Future }\end{array}$ & $\begin{array}{c}\text { Dutch Soil } \\
\text { Decree }\end{array}$ \\
\hline & & Metals & & & limit values & $\begin{array}{c}\text { proposed } \\
\text { limit values }\end{array}$ & limit values \\
\hline As (mg/kg) & $<2$ & 0.053 & $<0.050$ & $<0.050$ & 0.8 & 0.8 & 0.9 \\
\hline $\mathrm{Cd}(\mathrm{mg} / \mathrm{kg})$ & $<0.5$ & 0.011 & $<0.010$ & $<0.010$ & 0.03 & 0.03 & 0.04 \\
\hline $\mathrm{Cr}(\mathrm{mg} / \mathrm{kg})$ & 3160 & 0.26 & 0.21 & 0.22 & 0.5 & 2.6 & 0.63 \\
\hline $\mathrm{Cu}(\mathrm{mg} / \mathrm{kg})$ & 67 & 0.057 & $<0.050$ & $<0.050$ & 0.5 & 0.8 & 0.9 \\
\hline $\mathrm{Hg}(\mathrm{mg} / \mathrm{kg})$ & $<0.2$ & $<0.0020$ & $<0.0020$ & $<0.0020$ & 0.02 & 0.02 & 0.02 \\
\hline $\mathrm{Pb}(\mathrm{mg} / \mathrm{kg})$ & 7.1 & 0.11 & $<0.10$ & $<0.10$ & 1.3 & 1.3 & 2.3 \\
\hline Ni (mg/kg) & 836 & 0.053 & $<0.050$ & $<0.050$ & 0.75 & 0.75 & 0.44 \\
\hline $\mathrm{Zn}(\mathrm{mg} / \mathrm{kg})$ & 31 & 0.11 & $<0.10$ & $<0.10$ & 2.8 & 2.8 & 4.5 \\
\hline $\mathrm{Ba}(\mathrm{mg} / \mathrm{kg})$ & 180 & 0.70 & 0.28 & 0.43 & & 20 & 22 \\
\hline $\mathrm{Co}(\mathrm{mg} / \mathrm{kg})$ & 31 & 0.053 & $<0.050$ & $<0.050$ & & 0.5 & 0.54 \\
\hline Mo (mg/kg) & 128 & 2.3 & 0.50 & 1.4 & & 55 & 1 \\
\hline $\mathrm{Sb}(\mathrm{mg} / \mathrm{kg})$ & $<4$ & 0.11 & $<0.10$ & $<0.10$ & & 1 & 0.32 \\
\hline Se $(\mathrm{mg} / \mathrm{kg})$ & $<4$ & 0.21 & $<0.20$ & $<0.20$ & & 2 & 0.15 \\
\hline Sn (mg/kg) & $<4$ & 0.11 & $<0.10$ & $<0.10$ & & 1 & 0.4 \\
\hline \multirow[t]{2}{*}{$\mathrm{V}(\mathrm{mg} / \mathrm{kg})$} & 925 & 0.20 & 0.71 & 0.51 & & 2.5 & 1.8 \\
\hline & & Anions & & & & $\begin{array}{c}\text { target value } \\
\text { (1) }\end{array}$ & \\
\hline Bromide (mg/kg) & - & 4,0 & $<10$ & $<10$ & & 20 & $20^{(2)}$ \\
\hline Chloride $(\mathrm{mg} / \mathrm{kg})$ & - & 350 & 330 & 370 & & 1000 & $616^{(2)}$ \\
\hline Fluoride $(\mathrm{mg} / \mathrm{kg})$ & - & 98 & 100 & 98 & & 55 & $55^{(2)}$ \\
\hline Sulphate $(\mathrm{mg} / \mathrm{kg})$ & - & 230 & 240 & 250 & & 2200 & $2430^{(2)}$ \\
\hline
\end{tabular}

(1) For anions, the future VLAREMA legislation only imposes target values. These must be monitored, but are not grounds for exclusion. (2) When using building materials in places where direct contact with sea water or brackish water with a natural chloride content of more than $5000 \mathrm{mg} / \mathrm{L}$ is possible, no maximum emission values for chloride and bromide are imposed. Maximum emission values for fluoride and sulphate are multiplied by a factor of 4 .

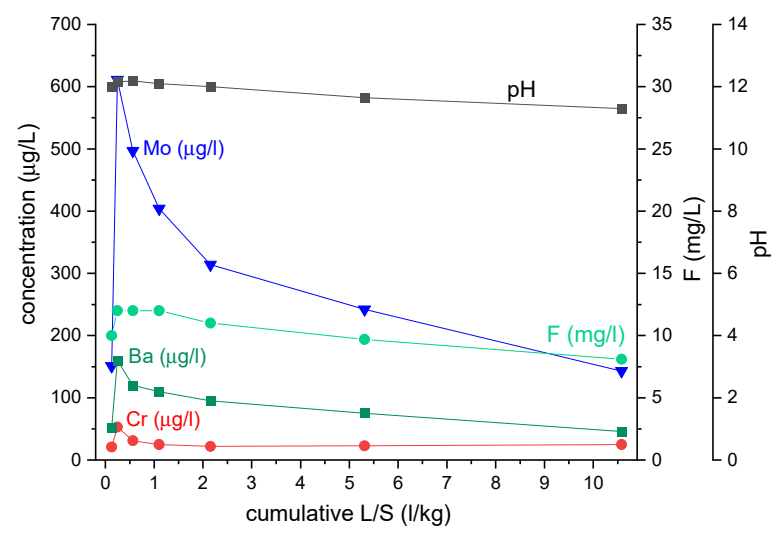

(a)

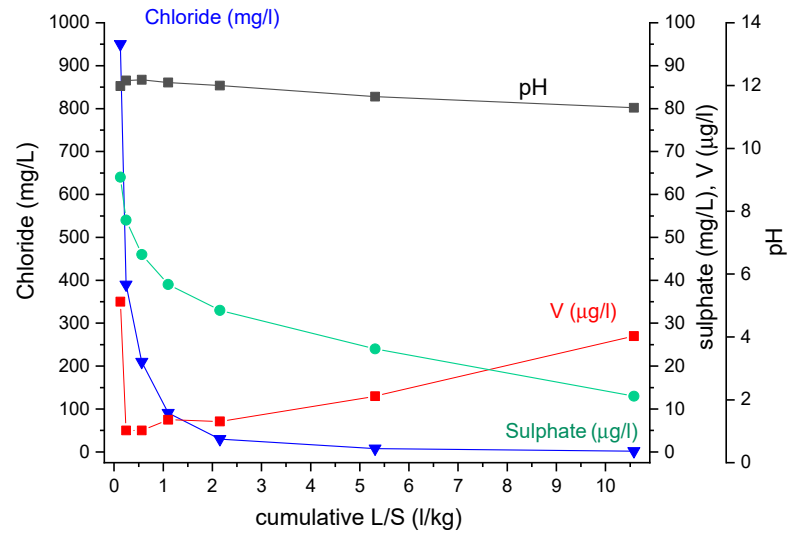

(b)

Figure 9. Leaching behavior of paver aggregates as a function of cumulative L/S. (a) Leaching of Ba, Cr, F and Mo (b) Leaching of chloride, sulphate and V. 
Table 4. Pearson's correlation coefficient based on the leachate concentrations in fractions 2 to 7 . Green is a strong correlation, orange is a medium correlation.

\begin{tabular}{ccccccccc}
\hline Pearson's & $\mathbf{p H}$ & $\mathbf{B a}$ & $\mathbf{C r}$ & $\mathbf{M o}$ & $\mathbf{V}$ & Chloride & Fluoride & Sulphate \\
\hline $\mathrm{pH}$ & & 0.89 & 0.50 & 0.89 & -0.97 & 0.67 & 0.99 & 0.94 \\
\hline $\mathrm{Ba}$ & 0.89 & & 0.79 & 0.99 & -0.85 & 0.91 & 0.89 \\
\hline $\mathrm{Cr}$ & 0.50 & 0.79 & & 0.79 & -0.40 & 0.95 & 0.45 & 0.72 \\
\hline $\mathrm{Mo}$ & 0.89 & 0.99 & 0.79 & & -0.83 & 0.93 & 0.89 & 0.99 \\
\hline $\mathrm{V}$ & -0.97 & -0.85 & -0.40 & -0.83 & & -0.59 & -0.95 & -0.89 \\
\hline chloride & 0.67 & 0.91 & 0.95 & 0.93 & -0.59 & & 0.67 & 0.88 \\
\hline fluoride & 0.99 & 0.89 & 0.45 & 0.89 & -0.95 & 0.67 & 0.94 \\
\hline sulphate & 0.94 & 0.99 & 0.72 & 0.99 & -0.89 & 0.88 & 0.94 \\
\hline
\end{tabular}

To further support the environmental quality, a concrete mix was made with crushed Carbstone pavers replacing all natural aggregates. This simulates what would happen in the so-called "second and third life", when pavements made with Carbstone pavers are demolished, and the resulting construction and demolition waste is used to make recycled aggregates for concrete. For the concrete mix, a worst-case scenario was selected in which both the fine $(0-4 \mathrm{~mm})$ and coarse $(4-20 \mathrm{~mm})$ natural aggregates are fully $(100 \%)$ replaced by recycled Carbstone paver aggregates. This situation will normally not occur in practice, because Carbstone pavers will always be mixed with other construction and demolition waste. Furthermore, most standards (e.g., [41]) recommend or, in some countries, only allow part of the natural aggregates to be replaced by recycled aggregates in certain applications because of their technical properties (higher water absorption, Los Angeles coefficient or Micro Deval value, etc.). Ordinary Portland cement (CEM I) was used, because this leads to the highest $\mathrm{pH}$ [42], and therefore, generally, the worst-case scenario for leaching. Cement with mineral admixtures such as blast furnace slag, fly ash, etc., reduce the calcium hydroxide content and refine the pore structure of the concrete through pozzolanic reactions. This enhances the compressive strength and durability of concrete made with these cements [43], and generally reduces the leaching of pollutants. After 28 days curing, the concrete was broken into $<4 \mathrm{~mm}$ aggregates and subjected to upstream column tests (according to CMA/2/II/A.9.1 (7 fractions) and NEN 7373:2004 standards). The leaching results show that using recycled Carbstone pavers as secondary aggregates in concrete does not constitute a risk for the environment (Table 5). In Figure 10, the leaching behavior is shown; it can be seen that, except for Ba, the leaching of most pollutants is very low.

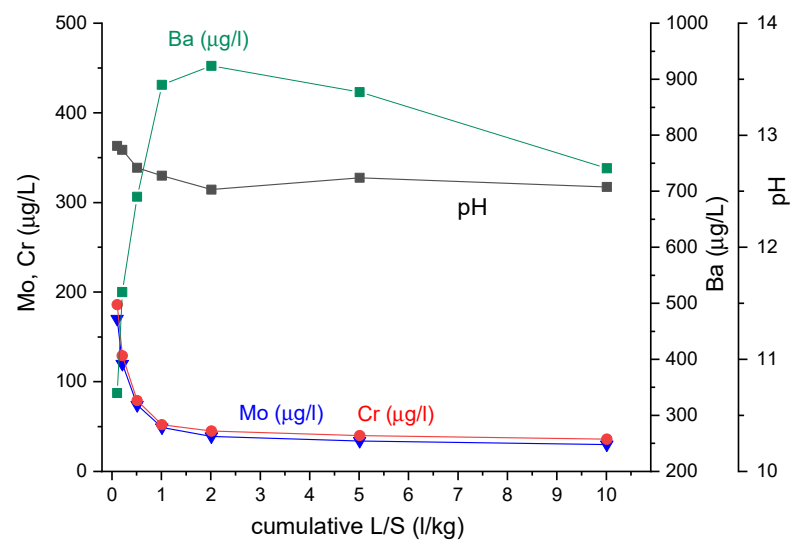

(a)

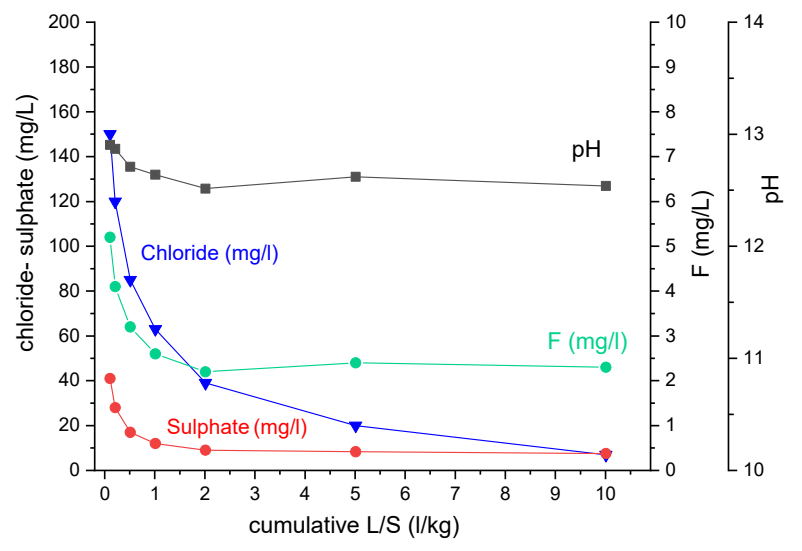

(b)

Figure 10. Leaching behavior of concrete aggregates as a function of cumulative L/S. (a) Leaching of $\mathrm{Ba}, \mathrm{Cr}$ and $\mathrm{Mo}$ (b) Leaching of chloride, sulphate and fluoride. 
Table 5. Results leaching concrete mix ( $350 \mathrm{~kg} / \mathrm{m}^{3}$ CEM I), with replacement of fine $(0-4 \mathrm{~mm})$ and coarse aggregates (4-20 $\mathrm{mm})$ with recycled aggregate from crushed Carbstone pavers. na = not analyzed.

\begin{tabular}{|c|c|c|c|c|c|}
\hline & $\begin{array}{c}\text { Column } \\
7 \text { Fractions -A }\end{array}$ & $\begin{array}{c}\text { Column } \\
7 \text { Fractions -B }\end{array}$ & $\begin{array}{c}\text { VLAREMA } \\
\text { Annex 2.3.2B }\end{array}$ & $\begin{array}{c}\text { VLAREMA } \\
\text { Future }\end{array}$ & $\begin{array}{c}\text { Dutch Soil } \\
\text { Decree }\end{array}$ \\
\hline Metals & & & limit values & proposed limit value & limit values \\
\hline As (mg/kg) & $0.007-0.020$ & na & 0.8 & 0.8 & 0.9 \\
\hline $\mathrm{Cd}(\mathrm{mg} / \mathrm{kg})$ & $<0.005$ & na & 0.03 & 0.03 & 0.04 \\
\hline $\mathrm{Cr}(\mathrm{mg} / \mathrm{kg})$ & 0.31 & 0.43 & 0.5 & 2.6 & 0.63 \\
\hline $\mathrm{Cu}(\mathrm{mg} / \mathrm{kg})$ & $<0.03$ & 0.01 & 0.5 & 0.8 & 0.9 \\
\hline $\mathrm{Hg}(\mathrm{mg} / \mathrm{kg})$ & na & na & 0.02 & 0.02 & 0.02 \\
\hline $\mathrm{Pb}(\mathrm{mg} / \mathrm{kg})$ & $<0.02$ & na & 1.3 & 1.3 & 2.3 \\
\hline $\mathrm{Ni}(\mathrm{mg} / \mathrm{kg})$ & $<0.03$ & na & 0.75 & 0.75 & 0.44 \\
\hline $\mathrm{Zn}(\mathrm{mg} / \mathrm{kg})$ & $<0.15$ & na & 2.8 & 2.8 & 4.5 \\
\hline $\mathrm{Ba}(\mathrm{mg} / \mathrm{kg})$ & 7.4 & 8.0 & & 20 & 22 \\
\hline $\mathrm{Co}(\mathrm{mg} / \mathrm{kg})$ & 0.035 & 0.02 & & 0.5 & 0.54 \\
\hline Mo (mg/kg) & 0.33 & 0.37 & & 55 & 1 \\
\hline $\mathrm{Sb}(\mathrm{mg} / \mathrm{kg})$ & $<0.020$ & na & & 1 & 0.32 \\
\hline Se $(\mathrm{mg} / \mathrm{kg})$ & 0.010 & na & & 2 & 0.15 \\
\hline $\mathrm{Sn}(\mathrm{mg} / \mathrm{kg})$ & 0.042 & $<0.010$ & & 1 & 0.4 \\
\hline $\mathrm{V}(\mathrm{mg} / \mathrm{kg})$ & $<0.010$ & $<0.005$ & & 2.5 & 1.8 \\
\hline Anions & & & & target value ${ }^{(1)}$ & \\
\hline Bromide (mg/kg) & 0.56 & 1.2 & & 20 & $20^{(2)}$ \\
\hline Chloride (mg/kg) & 250 & 219 & & 1000 & $616^{(2)}$ \\
\hline Fluoride (mg/kg) & 24 & 24 & & 55 & $55^{(2)}$ \\
\hline Sulphate (mg/kg) & 97 & 90 & & 2200 & $2430^{(2)}$ \\
\hline
\end{tabular}

\section{Conclusions}

In the range of 10-40 MPa, a clear trend is observed between compressive and tensile split strength for the carbonated pavers. The trend is similar to that observed for concrete, with a significant decline in $\mathrm{f}_{\mathrm{tsp}} / \mathrm{f}_{\mathrm{c}}$ ratio with increasing compressive strength. The trend shows that a minimum compressive strength in the range of 30-35 MPa must be reached to meet the requirement of 3.6 MPa split tensile strength. Further investigation is needed to verify the trend observed for higher compressive strengths, and other materials with carbonation potential.

The environmental properties of the Carbstone pavers comply with the current Flemish regulations, and the Dutch soil quality decree, when applied in contact with seawater or brackish water. After their service life, the Carbstone pavers can be recycled as aggregate in concrete without any environmental concerns. Concrete in which all natural aggregates have been replaced with recycled Carbstone pavers complied with all leaching limit values of VLAREMA and the Dutch soil decree.

Author Contributions: Conceptualization, H.K.K., P.N. and L.H.; Data curation, H.K.K. and P.N.; Investigation, H.K.K., P.N. and L.H.; Methodology, H.K.K. and P.N.; Writing-original draft, H.K.K., P.N. and L.H.; Writing-review and editing, H.K.K., P.N., L.H. and P.V.M. All authors have read and agreed to the published version of the manuscript. 
Funding: This research was funded by the Flemish Government under the funding scheme of Vlaanderen Circulair (project number 153). More information about the project is available (in Dutch) at https:/ / stad.gent/nl/ondernemen/economische-speerpunten/cleantech-cluster-regiogent/projecten-partnerschap/eerste-circulaire-voetpad-gent, (accessed on 8 July 2021).

Institutional Review Board Statement: Not Applicable.

Informed Consent Statement: Not Applicable.

Data Availability Statement: Not Applicable.

Acknowledgments: The authors thank Sten Janssen, Bo Peeraer, Myrjam Mertens and Anne-Marie De Wilde for the technical assistance.

Conflicts of Interest: The authors declare no conflict of interest. The funders had no role in the design of the study; in the collection, analyses, or interpretation of data; in the writing of the manuscript, or in the decision to publish the results.

\section{References}

1. USGS. Mineral Commodity Summaries-Cement; U.S. Geological Survey: Reston, VA, USA, 2016.

2. Scrivener, K.L.; John, V.M.; Gartner, E.M. Eco-Efficient Cements: Potential, Economically Viable Solutions for a Low-CO2, Cement-Based Materials Industry; United Nations Environment Programme: Paris, France, 2016; p. 50.

3. Ashby, M.F. Materials Selection in Mechanical Design; Elsevier Science: Amsterdam, The Netherlands, 2017.

4. Enkvist, P.-A.; Klevnäs, P. The Circular Economy a Powerful Force for Climate Mitigation; Material Economics: Stockholm, Sweden, 2019.

5. Müller, N.; Harnisch, J. A Blueprint for a Climate Friendly Cement Industry. WWF-Lafarge Conservation Partnership. 2008. Available online: https://wwf.panda.org/wwf_news/?151621/A-blueprint-for-a-climate-friendly-cement-industry (accessed on 8 July 2021).

6. Favier, A.; De Wolf, C.; Scrivener, K.; Habert, G. A Sustainable Future for the European Cement and Concrete Industry: Technology Assessment for Full Decarbonisation of the Industry by 2050; ETH: Zurich, Switzerland, 2018. [CrossRef]

7. Shi, C.; Qu, B.; Provis, J.L. Recent progress in low-carbon binders. Cem. Concr. Res. 2019, 122, 227-250. [CrossRef]

8. Grünhäuser, S.E.; Castro-Gomes, J. Carbonation curing influencing factors of Carbonated Reactive Magnesia Cements (CRMC) - A review. J. Clean. Prod. 2021, 305, 127210. [CrossRef]

9. Provis, J.L.; van Deventer, J.S.J. Alkali Activated Materials; Springer: Dordrecht, The Netherlands, 2014. [CrossRef]

10. Beretka, J.; de Vito, B.; Santoro, L.; Sherman, N.; Valenti, G.L. Utilisation of industrial wastes and by-products for the synthesis of special cements. Resour. Conserv. Recycl. 1993, 9, 179-190. [CrossRef]

11. Beretka, J.; Cioffi, R.; Marroccoli, M.; Valenti, G.L. Energy-saving cements obtained from chemical gypsum and other industrial wastes. Waste Manag. 1996, 16, 231-235. [CrossRef]

12. Quaghebeur, M.; Nielsen, P.; Horckmans, L.; Van Mechelen, D. Accelerated Carbonation of Steel Slag Compacts: Development of High-Strength Construction Materials. Front. Energy Res. 2015, 3, 12. [CrossRef]

13. Quaghebeur, M.; Nielsen, P.; Laenen, B.; Nguyen, E. Carbstone: Sustainable valorisation technology for fine grained steel slags and $\mathrm{CO}_{2}$. Refract. Worldforum 2010, 2, 75-79.

14. Mahoutian, M.; Chaallal, O.; Shao, Y. Pilot production of steel slag masonry blocks. Can. J. Civ. Eng. 2018, 45, 537-546. [CrossRef]

15. Di Maria, A.; Snellings, R.; Alaert, L.; Quaghebeur, M.; Van Acker, K. Environmental assessment of $\mathrm{CO}_{2}$ mineralisation for sustainable construction materials. Int. J. Greenh. Gas Control 2020, 93, 102882. [CrossRef]

16. Li, L.; Jiang, Y.; Pan, S.-Y.; Ling, T.-C. Comparative life cycle assessment to maximize $\mathrm{CO}_{2}$ sequestration of steel slag products. Constr. Build. Mater. 2021, 298, 123876. [CrossRef]

17. Stapsteen, C. Publieksrapport Stapsteen naar een Circulaire Stad. 2020. Available online: https://stad.gent/sites/default/files/ media/documents / Publieksrapport\%20Stapsteen\%20naar\%20een\%20circulaire\%20stad.pdf (accessed on 8 July 2021).

18. Nielsen, P.; Boone, M.A.; Horckmans, L.; Snellings, R.; Quaghebeur, M. Accelerated carbonation of steel slag monoliths at low $\mathrm{CO}_{2}$ pressure-Microstructure and strength development. J. $\mathrm{CO}_{2}$ Util. 2020, 36, 124-134. [CrossRef]

19. NBN. Concrete Paving Blocks—Requirements and Test Methods; NBN EN 1338:2003; Bureau voor Normalisatie: Brussel, Belgium, 2003.

20. Arıoglu, N.; Girgin, Z.C.; Arıglu, E. Evaluation of ratio between splitting tensile strength and compressive strength for concretes up to $120 \mathrm{MPa}$ and its application in strength criterion. ACI Mater. J. 2006, 103, 18-24.

21. Tran, N.L.; Graubner, C.-A. Uncertainties of concrete parameters in shear capacity calculation of RC members without shear reinforcement. In Proceedings of the Extended Abstracts of the 16th International Probabilistic Workshop, Vienna, Austria, 12-14 September 2018.

22. Walraven, J. Model Code 2010-First Complete Draft. 2010, Volume 2. Available online: https://en.calameo.com/books/0061506595 331 bab17cab (accessed on 8 July 2021). 
23. ACI Committee 318. In Building Code Requirements for Structural Concrete and Commentary; (ACI CODE-318-19); American Concrete Institute: Farmington Hills, MI, USA, 2019.

24. EN 1992-1-1:2004. In Eurocode 2: Design of Concrete Structures-Part 1: General Rules and Rules for Buildings; European Committee for Standardization (CEN): Brussels, Belgium, 2004.

25. Mombelli, D.; Mapelli, C.; Barella, S.; Di Cecca, C.; Le Saout, G.; Garcia-Diaz, E. The effect of chemical composition on the leaching behaviour of electric arc furnace (EAF) carbon steel slag during a standard leaching test. J. Environ. Chem. Eng. 2016, 4, 1050-1060. [CrossRef]

26. Albertsson, G.J.; Teng, L.; Engström, F.; Seetharaman, S. Effect of the Heat Treatment on the Chromium Partition in CaO-MgO$\mathrm{SiO}_{2}-\mathrm{Cr}_{2} \mathrm{O}_{3}$ Synthetic Slags. Metall. Mater. Trans. B 2013, 44, 1586-1597. [CrossRef]

27. Albertsson, G.J.; Teng, L.; Björkman, B. Effect of basicity on chromium partition in CaO-MgO- $\mathrm{SiO}_{2}-\mathrm{Cr}_{2} \mathrm{O}_{3}$ synthetic slag at 1873 K. Miner. Process. Extr. Metall. 2013, 123, 116-122. [CrossRef]

28. van der Sloot, H.A. Characterization of the leaching behaviour of concrete mortars and of cement-stabilized wastes with different waste loading for long term environmental assessment. Waste Manag. 2002, 22, 181-186. [CrossRef]

29. Van Gerven, T.; Cornelis, G.; Vandoren, E.; Vandecasteele, C. Effects of carbonation and leaching on porosity in cement-bound waste. Waste Manag. 2007, 27, 977-985. [CrossRef]

30. Costa, G.; Polettini, A.; Pomi, R.; Stramazzo, A. Leaching modelling of slurry-phase carbonated steel slag. J. Hazard Mater. 2016, 302, 415-425. [CrossRef] [PubMed]

31. VLAREMA. Besluit van de Vlaamse Regering tot Vaststelling van het Vlaams Reglement Betreffende het Duurzaam Beheer van Materiaalkringlopen en Afvalstoffen van 17 Februari 2012. Available online: https://navigator.emis.vito.be/mijn-navigator? woId=43991 (accessed on 9 July 2021).

32. VROM. Regeling bodemkwaliteit. Staatscourant 2007, 247, 67. Available online: https://wetten.overheid.nl/BWBR0023085/202101-21 (accessed on 9 July 2021).

33. Snellings, R. X-ray powder diffraction applied to cement. In A Practical Guide to Microstructural Analysis of Cementitious Materials; Scrivener, K.L., Snellings, R., Lothenbach, B., Eds.; CRC Press: Boca Raton, FL, USA, 2016; pp. 107-176.

34. Librandi, P.; Nielsen, P.; Costa, G.; Snellings, R.; Quaghebeur, M.; Baciocchi, R. Mechanical and environmental properties of carbonated steel slag compacts as a function of mineralogy and $\mathrm{CO}_{2}$ uptake. J. CO2 Util. 2019, 33, 201-214. [CrossRef]

35. Carino, N.J. Nondestructive testing of concrete: History and challenges. In Proceedings of the International Workshop on Civil Infrastructure Systems: Application of Intelligent Systems and Advanced Materials on Bridge Systems, Taipei, Taiwan, 10-12 January 1994; pp. 343-399.

36. Malhotra, V.M.; Carino, N.J. Handbook on Nondestructive Testing of Concrete; CRC Press: Boca Raton, FL, USA, 2003.

37. Popovics, S.; Rose, J.L.; Popovics, J.S. The behaviour of ultrasonic pulses in concrete. Cem. Concr. Res. 1990, 20, 259-270. [CrossRef]

38. Khan, S.R.M.; Noorzaei, J.; Kadir, M.R.A.; Waleed, A.M.T.; Jaafar, M.S. UPV method for strength detection of high performance concrete. Struct. Surv. 2007, 25, 61-73. [CrossRef]

39. Elvery, R.H.; Ibrahim, L.A.M. Ultrasonic assessment of concrete strength at early ages. Mag. Concr. Res. 1976, 28, 181-190. [CrossRef]

40. Saint-Pierre, F.; Philibert, A.; Giroux, B.; Rivard, P. Concrete quality designation based on ultrasonic pulse velocity. Constr. Build. Mater. 2016, 125, 1022-1027. [CrossRef]

41. CEN (European Committee for Standardization). EN 206-1 'Concrete: Specification, Performance, Production and Conformity: Annex E.3 Recommendation for the Use of Coarse Recycled Aggregates'; European Committee for Standardization: Brussels, Belgium, 2014.

42. Shafigh, P.; Yousuf, S.; Lee, J.C.; Ibrahim, Z. The effect of cement mortar composition on the pH value. In IOP Conference Series: Materials Science and Engineering; IOP Publishing: Bristol, UK, 2020; Volume 770, p. 012026. [CrossRef]

43. Cheng, A.; Chao, S.J.; Lin, W.T. Effects of Leaching Behavior of Calcium Ions on Compression and Durability of Cement-Based Materials with Mineral Admixtures. Materials 2013, 6, 1851-1872. [CrossRef] 